\title{
SISTEM IE TERKAIT PEWARIS PADA KELUARGA TRADISIONAL JEPANG
}

\author{
N.P.L. Wedayanti ${ }^{1}$, N.M.A.A. Dewi ${ }^{2}$ \\ ${ }^{123}$ Program Studi Sastra Jepang, FIB, Universitas Udayana, Denpasar \\ e-mail: luhur wedayanti@unud.ac.id, andry anita@unud.ac.id
}

\begin{abstract}
Abstrak
Masyarakat Jepang tradisional adalah masyarakat patrilineal yang sikap dan harapan masyarakatnya terhadap laki-laki sebagai penerus keberlangsungan keluarga cukup tinggi. Anak lakilaki memikul tanggung jawab pemujaan terhadap leluhur, keberlangsungan keluarga besar, dan hak terhadap warisan keluarga. Sistem ie adalah sistem yang mengatur pola keluarga masyarakat Jepang yang bukan saja mengenai aturan atau pola hidup keluarga batih akan tetapi juga mengatur keseluruhan aspek kehidupan keluarga tersebut. Aturan-aturan yang mengatur hak dan kewajiban kepala keluarga ataupun masing-masing anggota ie juga telah ditentukan dengan jelas, dan telah menyesuaikan dengan perkembangan masyarakatnya.
\end{abstract}

Kata Kunci : patrilineal, Jepang, ie

\section{Abstract}

Traditional Japanese society was a patrilineal society that had attitudes for men to preserve the family as a successor. The eldest son is always expected to be responsible for ancestor worship, wisely manage family inheritance to maintain the sustainability of the family. This system, le system, is a system that regulates all of the family members. Not only regarding how to behave toward family members but also the rules to choose the head of the family who will rule the whole of the family.

Key Words : patrilineal, Japan, le

\section{Pendahuluan}

Globalisasi dan modernisasi memang membawa perubahan besar pada pola hidup masyarakat dan sepertinya akan terus berlangsung di masa depan tanpa ada batas waktu. Orientasi hidup masyarakat pun berubah masif dari tradisional menjadi modern dan perlahan meninggalkan cara hidup maupun nilai yang dipercaya beratus tahun karena dianggap kurang mendukung upaya memajukan hidup individu di masyarakat tersebut. Sebagai contoh di Jepang, negara Jepang dilihat dari kacamata sebagian orang di luar Jepang tentu yang terlihat adalah negara yang maju tanpa meninggalkan budayanya. Hal ini karena Negara Jepang tidak hanya mempromosikan teknologinya, tetapi juga kekayaan budaya tradisionalnya. Hal tersebut membuat pergolakan sosial dalam masyarakat Jepang luput tak terlihat, mengenai bagaimana para orang tua dan budayawan senior Jepang juga kawatir akan pendangkalan nilai-nilai budaya(Devi, 2014; Ghiamitasya, 2012; Utari, 2008). Meskipun tanpa dapat kita pungkiri bahwa kecanggihan teknologi memang sungguh membantu pelestarian teknologi dan penyimpanan kekayaaan budaya tersebut untuk diwariskan kepada generasi muda mereka di masa depan dalam metode tertentu.

Sejak Jepang menjadi negara industri, banyak perusahaan yang dibangun di kota besar dan mendorong anak laki-laki untuk bekerja di kota meninggalkan kampung halamannya. Disamping itu, persamaan hak antara pria dan wanita juga memberi angin segar pada wanita untuk dapat berkarir dan mandiri. Hal tersebut ternyata membawa Jepang pada permasalahan sosial yang pelik dewasa ini. Fenomena bankonka, yaitu para wanita yang menikmati menjadi wanita karir, semakin berdaya dan memilih untuk hidup sendiri. Begitu juga dengan para pria yang enggan menikah karena tanggung jawab sebagai kepala keluarga sangat tinggi, membuat mereka hanya fokus pada karir. Berpalingnya para 
JPBJ, Vol. 7 No. 1, Februari 2021

ISSN: 2613-9618

generasi muda dari pernikahan tentu mengurangi angka kelahiran (shoshika)(Amaliatun, 2010; Azhar, 2017; Devi, 2015; Novianti \& Dianto, 2008; Roosiani, 2017; Widarahesty \& Ayu, 2014). Berkurangnya jumlah anak-anak sebagai penerus keluarga pada khususnya tentu menjadi kekhawatiran mendalam di Jepang saat ini. Bukan hanya kelangsungan negaranya berkaitan dengan tenaga kerja, tetapi juga kebutuhan keluarga yang memiliki tradisi untuk dilestarikan.

\section{Metode}

Penelitian ini merupakan penelitian kualitatif yang menggunakan beberapa referensi terkait sebagai bahan acuan untuk dapat memberikan kajian terhadap sistem ie yang ada pada keluarga tradisional di Jepang. Karya tulis ini memberikan gambaran singkat terkait bagaimana sistem ie menentukan keanggotaan dalam keluarga besarnya karena tidak terbatas pada kekerabatan yang berdasarkan hubungan kandung atau sedarah. Demikian juga hak dan kewajiban yang diemban seorang kacho sehingga pemilihannya pun harus dilakukan dengan hati-hati dan berorientasi pada kepentingan keluarga bersama. Berikut adalah kajian pustaka yang dijadikan referensi dalam memahami pola ie dalam masyarakat Jepang tradisional.

Widarahesty \& Ayu (2014) mengkaji terkait fenomena penurunan angka kelahiran pasca Perang Dunia II yang disebabkan oleh transformasi besar-besaran yang terjadi di Jepang. Ditulis bahwa modernisasi di Jepang memberi dampak positif terkait pengakuan terhadap perempuan. Sudut pandang ini membawa perubahan signifikan pada pola pikir dan pola hidup masyarakat Jepang selanjutnya. Banyak wanita yang merasa lebih nyaman dan mampu hidup sendiri, sehingga memicu fenomena bankonka, hikonka, memilih tidak punya anak, ataupun memilih punya anak satu orang saja (hitoriko). Kajian dalam penelitian ini berkaitan erat dengan penelitian yang peneliti lakukan saat ini. Dengan menurunnya angka kelahiran di Jepang, akan muncul masalah-masalah terkait proses pewarisan hak dan kewajiban keluarga yang membutuhkan penerus (anak) laki-laki, dan jalan keluar yang dilakukan kemungkinan mengandung pengikisan nilai-nilai konvensional mengenai pranata ie dalam keluarga di Jepang.

Penelitian yang dilakukan Kurosu di kota Shimomoriya, Jepang menjelaskan adanya tiga proses yang biasa dilakukan sebagai strategi memberikan warisan. Proses adopsi ini dibedakan menjadi tiga, yaitu adopsi anak laki-laki (futsu-yoshi), adopsi menantu laki-laki (mukoyoshi), adopsi suami (nyufu). Adopsi ini dilakukan karena dalam keluarga wanita, memang tidak ada laki-laki yang bisa mendampingi wanita sebagai kepala keluarganya. Proses adopsi seperti ini sangat biasa dilakukan di Kota Shimomoriya sejak ratusan tahun sebelumnya, mereka yang diadopsi biasanya adalah anak laki-laki yang bukan sulung. Bila dalam keluarga tersebut memiliki anak laki-laki lebih dari satu orang, maka anak laki-laki yang bukan sulung diharapkan untuk keluar dari rumah. Kasus adopsi terhadap anak lakilaki satu-satunya dalam satu keluarga menuju keluarga wanita, biasanya dikarenakan berbagai macam alasan, salah satunya yaitu motivasi ekonomi (Kurosu, 2013).

Referensi yang ditulis (Tobing, 2006) menjelaskan mengenai struktur masyarakat feodal Jepang sesuai dengan tahapan sejarah Jepang. Nilai-nilai modernisasi terjadi setelah Perang Dunia II mengubah bentuk keluarga Jepang yang awal mulanya keluarga besar menjadi hanya keluarga batih (keluarga inti) yang lebih kecil. Perubahan ini tentu saja membawa berbagai perubahan konsep dalam pranata keluarga. Tobing juga menjelaskan dengan detil mengenai sistem ie yang menjiwai ideologi keluarga di Jepang. Sistem pewarisan hak dan kewajiban, dan pemilihan pewaris dalam keluarga. Dalam kondisi ideal, pewaris dalam keluarga adalah seorang anak laki-laki sulung. Meskipun anak laki-laki lahir bukan sebagai anak pertama, akan tetapi ketika dia adalah anak laki-laki pertama, maka dia akan diperlakukan sebagai anak sulung pewaris keluarga sejak kecil. Segala tanggung jawab berkaitan tentang mengurus kelurga, tetua dan leluhur serta warisan keluarga menjadi hak anak laki-laki sulung. Kasus keluarga yang tidak memiliki anak laki-laki kandung beberapa sistem pengangkatan pewaris dilakukan sebagai cara meneruskan pranata ie dalam keluarga, diantaranya mengangkat anak laki-laki dan atau mengangkat menantu lakilaki menjadi kepala keluarga. 
JPBJ, Vol. 7 No. 1, Februari 2021

ISSN: 2613-9618

\section{Hasil dan Pembahasan}

Masyarakat Jepang merupakan masyarakat penganut pola animisme sebagai sistem kepercayaan yang menjiwai pola hidup maupun ideologi mereka secara umum. Sebagian besar bagian dari alam akan terepresentasi dalam kekuatan para dewa maupun dewi yang sangat dipercaya mampu melindungi umat manusia. Jaman kuno di Jepang, masih belum memiliki pranata patrilineal, bahkan pemimpin di jaman Yamato adalah seorang ratu.

Salah satu perubahan pandangan ini dikatakan karena pengaruh konfusianisme yang masuk ke Jepang (Anwar, 2007) Ajaran ini berkembang pesat dan menjiwai pola hidup individu dalam masyarakatnya di Jepang. Pandangan ini digunakan sebagai dasar untuk mengatur masyarakat Jepang di jaman selanjutnya untuk patuh kepada pemimpinnya. Pranata masyarakat yang memusatkan diri para laki-lakipun sejak saat itu mulai diatur dengan detail, seperti misalnya peran-peran sentral dan signifikan yang dimiliki laki-laki dalam keluarga ataupun masyarakat. Konsep kepala keluarga sebagai orang yang paling dihormati dalam keluarga merupakan bentuk adaptasi ajaran konfusianisme yang menjunjung tinggi nilai keharmonisan. Keteraturan dan keharmonisan hanya akan terwujud bila setiap orang memahami peran dan tanggung jawabnya masing-masing, dan menghormati kaisar sebagai orang yang paling dihormati. Konsep kazoku kokka, yang mana kaisar adalah kepala keluarga bagi keluarga-keluarga di Jepang dan lingkupnya yang lebih kecil adalah kepala keluarga sebagai pemimpin dari keluarganya sangat mendarah daging dalam jiwa orang Jepang.

\section{A. Pengertian Sistem le}

Dalam bahasa Jepang kata ie memiliki dua arti yaitu 'bangunan rumah' dan juga berarti 'suatu sistem kekerabatan luas yang terbatas (limited extended family) yang ditarik dari garis patrilineal (Anwar, 2007)Terminologi le ini memang cukup sulit untuk dijelaskan dalam budaya atau bahasa lain meskipun budaya atau masyarakat penganut sistem patrilineal cenderung memiliki sistem yang hampir sama pada sistem kekerabatannya. Definisi ini secara denotatif berarti rumah tinggal. Di samping itu, istilah ie ini juga dapat dimaknai sebagai sebuah sistem kekerabatan yang didasarkan pada adanya kepentingan yang sama dalam rangka menjaga keberadaan dan kelangsungan hidup keluarga (Kuwayama, 2001). le ini sangat kental muatan kultur pola hidup masyarakat Jepang, seperti yang telah disampaikan sebelumnya, pola kekerabatan masyarakat patrilineal kerap memiliki aturan atau pranata yang mirip dalam mengatur masyarakatnya.

Sistem ini (Sakane, 2017)memiliki beberapa karakter diantaranya yang utama adalah memiliki sistem pewarisan yang tunggal. Sebelum masa Jepang modern, harta warisan keluarga diturunkan dengan dibagi rata antara pewaris dalam keluarga tersebut tanpa memperhitungkan anak sulung ataupun bungsu. Akan tetapi setelah masa Jepang modern, harta keluarga hanya diwariskan kepada anak sulung, untuk diwariskan dengan pola yang sama selanjutnya. Hal ini untuk mencegah berkurangnya warisan keluarga jika dipecah atau dibagi secara kontinu di masa selanjutnya. Dengan menjaga jumlah harta tetap sama, pewaris yaitu anak laki-laki sulung dapat mempertahankan perekonomian keluarga besar dalam ie, sehingga dapat menjamin kesejahteraan dan keberlangsungan keluarga tersebut.

Karakter kedua adalah adanya nama keluarga yang dibuat untuk mencerminkan kebaikan reputasi dari keluarga tersebut. Karakter selanjutnya adalah kurangnya regulasi yang tegas mencegah pewaris bukan keluarga, atau laki-laki yang tidak memiliki hubungan darah menjadi pewaris. Hal ini terjadi karena dalam keluarga tersebut tidak memiliki anak laki-laki sebagai pewaris. Karena tidak adanya regulasi yang tegas mengharuskan kerabat laki-laki kandung yang boleh mewarisi ie, pengangkatan anak laki-laki ataupun menantu lakilaki diperbolehkan untuk menjadi penerus untuk memimpin ie. Karakter keempat adalah pengembangan atau perluasan keluarga ie menjadi beberapa cabang pun, keluarga cabang 
tersebut harus tetap berafiliasi dengan keluarga utama sesuai struktur dan hirariki keluarga. Karakter kelima adalah adanya pemujaan kepada leluhur yang dilakukan sebagai tanggung jawab penting pemimpin ie beserta anggotanya. Pemikiran bahwa para leluhur yang merintis sistem ie, dan segala harta yang dinikmati oleh anggota ie tersebut adalah warisan dari nenek moyang memberikan kesadaran pada anggota ie untuk selalu mengutamakan pemujaan kepada luluhurnya.

Cakupan keluarga dalam sistem ie cukup luas karena tidak hanya mencakup keluarga yang memiliki hubungan kekerabatan, akan tetapi juga, mereka yang terlibat dalam organisasi atau struktur bisnis keluarga ie tersebut. Sehingga penting untuk memaparkan mengenai keanggotaan ie. Terdapat empat prinsip dasar untuk mengindentifikasi dan menggolongkan orang-orang yang dapat dianggap sebagai anggota ie (Tobing, 2006), yaitu :

1. kerabat hubungan darah dari garis keturuan langsung yang dihitung secara patrilineal. Anggota kerabat yang masuk kelompok in adalah kakek, nenek, anak laki-laki sulung bersama istrinya, dan lain-lain yang merupakan anggota kerabat langsung.

2. kerabat hubungan darah seketurunan beserta keluarga mereka, seperti saudara kandung laki-laki dan istrinya, kemenakan laki-laki dengan istrinya, dan lain-lain,

3. kerabat fiktif, yaitu mereka yang menjadi anggota ie tidak mempunyai hubungan darah baik dari garis keturunan langsung maupun tidak langsung. Mereka adalah hokonin, yaitu pembantu atau pekerja yang sudah lama bekerja. Mereka dapat diangkat menjadi anggota ie beserta dengan keluarganya secara turun temurun.

4. kerabat fiktif seketurunan yang tidak ada hubungan darah langsung, misalnya mukoyoshi beserta keluarga yang diangkat menjadi anggota ie.

Tidak semua keluarga bisa memiliki struktur sistem ie yang luas dan bertahan cukup lama. Beberapa diantaranya langsung putus hanya sampai beberapa generasi, salah satu penyebabnya adalah karena ie tersebut tidak cukup stabil dari segi perekonomian. le yang kurang mapan cenderung memiliki anggota semakin sedikit dan kemungkinan anak laki-laki dalam ie tersebut akan pergi meneruskan ie lain. Oleh sebab itu, Torigoe (dalam Anwar, 2007) memaparkan beberapa hal yang menjadi syarat terbentuknya ie tersebut, yaitu :

1. mempunyai harta warisan (kazan) sebagai harta kekayaan (zaisan). Berdasarkan kazan inilah dikelola pekerjaan ie (kagyou) dalam bentuk satuan manajemen.

2. menekankan pada pemujaan terhadap arwah leluhur dari yang merupakan pendahulu dari garis keturunan mereka

3. menekankan eksistensi keturunan langsung dari generasi ke generasi yang memandang penting kemakmuran bersama

Dari definisi maupun karakter ie tersebut, dapat dijelaskan bahwa anggota ie secara sadar untuk selalu mengutamakan kepentingan ie dan kebutuhan kacho sebagai kepala keluarganya. Dan sebagai balasannya, keluarga atau anggota ie tersebut mendapatkan perlindungan dan jaminan dalam kesejahteraan maupun keamanan mereka masing-masing.

\section{B. Hak dan Kewajiban Pemimpin le (Kacho)}

Sebuah le dipimpin oleh seorang Kacho, yang pemilihannya sebagai kacho atau pemimpin ie telah dibentuk dari anak laki-laki sulung tersebut dari kecil. Seorang calon kacho telah diperlakukan dengan sangat istimewa sejak mereka masih kecil. Pembentukan mereka sebagai calon pemimpin yang unggul dan bertanggung jawab selalu diutamakan dibandingkan dengan saudara-saudaranya yang lebih muda, apalagi jika dibandingkan dengan saudara perempuannya. Para pemimpin ie atau seorang kepala keluarga diijinkan untuk mandi lebih awal, ketika makan bersama kehadirannya ditunggu oleh anggota keluarga lain dan dilayani paling awal (Onogwu, 2015). Bukan hanya diistimewakan, seorang kacho juga memiliki kekuasaan dalam mengatur dan mengelola ie tersebut dengan persetujuan dan kepercayaan penuh dari anggota ie-nya. 
Kekuasaan yang dimiliki oleh kachou bersumber pada kedudukan statusnya sebagai ahli waris dan penerus ie. Adapun kekuasaan-kekuasaan kacho dalam ie antara lain:

1. kekuasaan untuk mengawasi dan mengontrol anggota ie serta mengatur perekonomian ie (kakei). Oleh karenanya kacho dengan kekuasaan dari perekonomian, juga sangat bertanggung jawab dan berkuasa terkait kelangsungan hidup anggota keluarga lainnya.

2. kekuasaan untuk memberikan perintah, mengawasi, dan membagi-bagi pekerjaan kepada anggota-anggota ie. kacho mempunyai kekuasaan untuk mengawasi kekayaan ie.

3. kekuasaan untuk menentukan keputusan-keputusan yang terakhir berkaitan dengan masalah perkawinan dan pemilihan pekerjaan.

4. kekuasaan untuk mengeluarkan anggota ie dari registrasi keluarga yang dianggap telah menentang aturan-aturan ie dan wewenang kacho

5. wewenang untuk memberikan bagian kecil dari kekayaan ie kepada adik laki-lakinya apabila mereka telah menikah.

Jika dilihat dari peran dan kewenangan yang dimiliki oleh kachou, wewenang yang dimiliki cukup besar untuk membuat anggota keluarga lainnya merasa hidupnya memang tergantung pada kachou mereka. Dalam rumah tangga le, setiap orang memiliki tanggung jawabnya masing-masing. Misalnya adalah anggota wanita dalam ie tersebut. Seorang wanita hanya boleh mengerjakan urusan domestik rumah tangga. Posisi mereka sangat rendah dalam struktur keluarga, dengan semua kepentingannya yang bukan utama, bahkan mereka tidak bisa menentukan nasibnya sendiri. Seorang anak perempuan tidak menikah tanpa ijin dari kepala keluarga. Mereka dapat menjadi alat politik untuk mendapatkan kerabat dengan reputasi ie yang lebih baik melalui perkawinan. Memiliki kerabat dengan reputasi yang baik dipercaya dapat membawa keberuntungan bagi ie keluarga asalnya.

Sebaliknya jika seorang wanita dalam keluarga ie tersebut tidak dapat melaksanakan tugasnya di rumah tangga tersebut dengan baik, seperti mengurus anak dan dapur serta keperluannya yang tidak sesuai. Maka wanita tersebut, jika dia bukan istri kepala keluarga ie (kacho), tanpa memperhitungkan pertimbangan dari sang suami, kacho dapat menceraikan wanita tersebut dan mengembalikannya ke keluarga asalnya. Oleh sebab itu, pernikahan yang mengutamakan perasaan kasih bukan prioritas dalam keluarga tradisional tersebut.

Kewajiban dalam melaksanakan pemujaan kepada leluhur dan tanggung jawab keluarga di masyarakat juga menjadi kewajiban seorang kepala keluarga ie. Leluhur atau orang tua yang telah meninggal sangat dihormati dalam keluarga ie, karena mereka diyakini sebagai pembentuk ie dan telah mewariskan harta yang dapat dikelola dan dinikmati penerusnya.

\section{Proses Pemilihan Pewaris dalam Sistem le}

Masyarakat Jepang sebagai masyarakat yang berpranata patrilineal, secara tidak langsung menuntut setiap keluarga untuk memiliki anak laki-laki sebagai pewaris hak dan kewajiban keluarga. Sistem patrilineal yang menarik garis lurus dari keturunan pihak laki-laki, membuat keluarga-keluarga yang tidak memiliki pewaris laki-laki harus berusaha menemukan upaya penyelesaian terkait masalah tersebut. Seperti yang telah disampaikan sebelumnya, bahwa tidak ada aturan yang sangat ketat yang mengharuskan pewaris sebuah ie tersebut haruslah kerabat dekat yang sedarah (Sakane, 2017). Oleh sebab itu, disampaikan beberapa cara pemilihan seorang laki-laki untuk dapat menjadi kacho (atau kepala keluarga atau pemimpin sebuah ie (Anwar, 2007; Tobing, 2006)diantaranya adalah :

1. melalui pertalian darah, yaitu diangkat dari chounan

2. mengangkat pewaris yang disebut dengan yoshi

3. mengangkat pewaris yang disebut dengan mukoyoshi 
Pola pengangkatan pewaris tersebut sangat penting dilakukan dalam rangka mempertahankan keberlangsungan ie. Seorang anak laki-laki sulung akan dipanggil chonan dengan pengistimewaan akan menyertainya beranjak dewasa. Anak laki-laki sulung ataupun adopsi sama-sama dididik sehingga dapat menjadi kepala rumah tangga yang bertanggung jawab dan menjaga nama baik keluarga besarnya. Di samping pengangkatan anak tersebut, terdapat pula pengangkatan menantu laki-laki menjadi kepala keluarga. Proses ini terjadi apabila ada keluarga yang tidak memiliki anak laki-laki, maka keluarga tersebut menggunakan jalan dengan meminang pemuda untuk nantinya masuk sebagai anggota baru dalam keluarga mempelai wanitanya (Kurosu, 2013; KUROSU, 1997; Morris, 1895; Onogwu, 2015).

Pernikahan yang bertujuan mengangkat menantu laki-laki menjadi kacho suatu saat nanti memiliki proses yang berkebalikan dengan peminangan menantu wanita. Jika dalam perkawinan patrilineal yang lazim, mempelai wanita akan meninggalkan keluarga asalnya, dan tinggal di keluarga laki-laki yang diikuti penyesuaian-penyesuaian seperti mengganti nama keluarga asalnya mengikuti nama keluarga suaminya. Mempelai laki-laki yang dipinang akan datang ke keluarga wanita, dan mengikuti nama keluarga istrinya. Meskipun dipinang untuk dijadikan kacho, akan tetapi posisi tersebut tidak datang atau diterima dengan mudah tanpa pembuktian. Terutama apabila kepala keluarga utamanya (mertua lakilaki) masih hidup dan mampu mengelola ie dengan sangat baik.

\section{Simpulan}

Sistem patrilineal di Jepang ini dapat berlangsung lama karena mereka juga memiliki sistem pewarisan yang diatur oleh norma-norma kebiasaan seperti berikut, pemimpim ie pada umumnya disebut kacho, yaitu anak kandung laki-laki atau kemungkinan juga anak angkat atau menantu laki-laki yang sudah diumumkan di dalam dan di luar ie mengenai status pengangkatanannya sebagai ahli waris. Sistem ie sangat kompleks dan dibuat dengan sangat matang untuk mengatur pola hidup masyarakat tradisional Jepang yang berasaskan kuat pada nilai-nilai konfusianisme. Pengangkatan pewaris keluarga atau kepala keluarga dilakukan dengan hati-hati dan regenerasi kepemimpinannya juga dilakukan sajak dini, sehingga didapatkan seorang kepala keluarga yang bijak dan dapat mengelola keberlangsungan ie serta menjaga nama baik keluarga.

\section{Ucapan Terima kasih}

Pada kesempatan ini penulis menyampaikan ucapan terima kasih kepada Rektor Universitas Udayana dan Ketua Lembaga Penelitian dan Pengabdian Kepada Masyarakat (LPPM) Universitas Udayana atas dukungan serta bantuan Dana PNPB Universitas Udayana, sehingga penelitian ini dapat terselesaikan. Penelitian ini didanai DIPA PNPB TA 2019 Universitas Udayana. Semoga Penelitian ini dapat memberikan sumbangan ilmiah, terutama dalam bidang pengembangan kebahasaaan dan kebudayaan Jepang.

\section{Daftar Pustaka}

Amaliatun, S. (2010). PERBANDINGAN PERMASALAHAN GENDER DI JEPANG DAN INDONESIA. In JURUSAN SASTRA JEPANG, UNIV. PADJADJARAN (Vol. 7, Issue 9).

Anwar, E. N. (2007). Ideologi Keluarga Tradisional "IE " dan Kazoku Kokka pada Masyarakat Jepang Sebelum dan Sesudah Perang Dunia II. Wacana, Journal of the Humanities of Indonesia, 9(2), 194. https://doi.org/10.17510/wjhi.v9i2.212

Azhar, U. Al. (2017). REPRODUKSI KULTURAL MITOS “PEREMPUAN IDEAL "JEPANG MELALUI SERIAL TV OSHIN KARYA SUGAKO HASHIDA TAHUN 1983 REPRODUCTION OF CULTURAL MYTH ON JAPANESE "IDEAL WOMAN" THROUGH OSHIN TV SERIES BY SUGAKO HASHIDA 1983. 63-74.

Devi, R. (2014). DALAM TIGA NOVEL KARYA OGAWA YOKO. Lingua Cultura, 8(2), 77-84. 
Devi, R. (2015). Struktur Keluarga Jepang dan Implementasinya dalam Keluarga Indonesia. In Sastra Kita: Kini, Dulu, dan Nanti.

Ghiamitasya, M. (2012). Perubahan Peran Ayah dalam Pengasuhan Anak di Jepang pada Era Shoushika. Japanology, 1(1), 107-115.

Kurosu, S. (2013). Adoption and Family Reproduction in Early Modern Japan. In Economic Review (Keizai Kenkyu) (Vol. 64, Issue 1, pp. 1-12). http://www.ier.hitu.ac.jp/English/publication/ER/\%5Cnhttp://search.ebscohost.com/login.aspx?direct=true $\& d b=e c n \& A N=1368801 \&$ site $=$ ehost-live \&scope $=$ site

KUROSU, S. (1997). Adoption as an Heirship Strategy? : a Case from a Northeastern Village in Pre-industrial Japan. Japan Review, 9, 171-189. https://doi.org/10.2307/25791007

Kuwayama, T. (2001). The Discourse of le ( Family ) in Japan 's Cultural Identity and Nationalism. Japanese Review of Cultural Anthropology, 2, 3-37., 2, 3-37.

Morris, R. (1895). Adoption in Japan. The Yale Law Journal, 4(4), 143-149.

Novianti, N., \& Dianto, E. (2008). Analisis Faktor Penyebab Berkurangnya Upacara Pernikahan Shinzen Kekkon di Jepang, Khususnya Daerah Kansai. Lingua Cultura, 2(2), 180. https://doi.org/10.21512/lc.v2i2.309

Onogwu, E. O. (2015). Reversing patriarchy: A literary examination of adopted husbands (Mukoyoshi) in Japan. Rupkatha Journal on Interdisciplinary Studies in Humanities, 7(3), 140-148.

Roosiani, I. (2017). Kedudukan Perempuan dalam Masyarakat Jepang. Wahana, 1(13), 70 79. https://journal.unpak.ac.id/index.php/wahana/article/download/672/575

Sakane, Y. (2017). The Characteristics and Global Position of the Japanese ie System. Studies in the Humanities and Sciences, 57(2), 47-61.

Tobing, E. (2006). Keluarga tradisional Jepang dalam perspektif sejarah dan perubahan sosial.

Utari, S. (2008). Mengikis Ketidakadilan Gender Dalam Adat Bali. Jurnal Studi Jender SRIKANDI, 7(1), 1-15.

http://ojs.unud.ac.id/index.php/srikandi/article/download/2893/2062

Widarahesty, Y., \& Ayu, R. (2014). Fenomena Penurunan Angka Kelahiran di Jepang Pasca Perang Dunia II Sampai 2012. 177 Jurnal AL-AZHAR INDONESIA SERI PRANATA SOSIAL, 2(3), 177-197. 